\title{
ASSESSMENT OF BUSINESS ENVIRONMENT OF WOMEN INVOLVED IN MICRO, SMALL, AND MEDIUM ENTERPRISES (MSMES) IN THE PHILIPPINES: A COMPARATIVE STUDY WITH SELECT ASEAN COUNTRIES
}

\author{
Myrtle Faye Laberinto Solina \\ Faculty of Management and Development Studies \\ University of the Philippines Open University/Graduate Student \\ Los Baños, Laguna 4031 \\ myrtlefaye_solina@yahoo.com
}

Received: $09^{\text {th }}$ August 2020/ Revised: $29^{\text {th }}$ August 2020/ Accepted: $17^{\text {th }}$ November 2020

How to Cite: Solina, M. F. L. (2020). Assessment of business environment of women involved in Micro, Small, and Medium Enterprises (MSMEs) in the Philippines: A comparative study with select ASEAN countries. Journal of ASEAN Studies, 8(2), 191-211.

https://doi.org/10.21512/jas.v8i2.6617

\begin{abstract}
The United Nations Conference on Trade and Development in 2017 states that women are deemed important part of a trade. They take part in a wide range of activities in the industry - produce products, commerce of goods across borders, run and own trading firms, and make up a large part of the workforce in exportoriented businesses. Nevertheless, women's potential and skills in trade is still too often held back by the many constraints. Hence, the research endeavours to describe the current demographics, roles, and experiences of women involved in MSMEs, provide information on the current policies programs and services and how these are comparable and contrasting, not to mention recommend measures to address the impeding factors in the Philippines to be compared with Singapore and Myanmar using available secondary information. Through surveys and purposive sampling, the research results show that women's participation in economic activity, in particular in MSMEs, is primarily affected by conditions that catalyze engagements.
\end{abstract}

Keywords: ASEAN, MSMEs, Women, Business Environment, Philippines

\section{INTRODUCTION}

The ASEAN Coordinating Committee on Micro, Small, and Medium Enterprises (ACCMSME) in 2020 states that small and medium enterprises are key drivers and contributors 
to economic growth, account for $88,8 \%$ to $99,9 \%$ of all establishments, and generate between $51,7 \%$ and $97,2 \%$ of total employment. As such, the region would give new emphasis on assisting and promoting micro, small and medium enterprises (MSMEs) in its economic integration through a more structured and targeted MSME program (ASEAN Secretariat, 2015a). The program will be put in place to enhance MSME competitiveness, resilience, and to enable significant benefits from ASEAN integration through various measures. It may start with promotion of productivity, use of technology, and adaption of innovation. It is also essential to increase access to finance by developing and enhancing current framework, strengthening traditional infrastructure, enhancing policy environment and measures that foster alternative and non-traditional financing. Besides, it can be done by enhancing market access and internationalization through the development of support schemes and integration into the global supply chains, e.g., promotion of collaboration with multinational corporations (MNCs) and large enterprises, foster the use of e-Commerce, and boost strategies to promote exports through export clinics, advisory services and rules of origin (ROO) utilization. Lastly, it occurs essential to enhance MSME policy and regulatory environment that supports intra- and intergovernmental cooperation and coordination mechanism through the involvement of MSMEs in the decision-making process. It is all to enable better representation of MSME interests, extend assistance to microenterprises in the informal sector and their integration, and streamline processes involved in obtaining permits and business registrations to enable less costly and faster business formation (ASEAN Secretariat, 2015a).

True to its overarching message, the region also recognizes the critical role of women in entrepreneurship. As such, realization of these principles requires the active engagement of all ASEAN Member States (AMS), sectoral bodies under the three pillars of ASEAN, and stakeholders including civil society, academia, media, and private sectors (ASEAN Secretariat, 2015b). Furthermore, ASEAN Secretariat (2015a) states that promotion of entrepreneurship and social capital development by creating a more conducive environment for entrepreneurship. Some of the ways to realize this is through the ASEAN Online Academy and enhancing social capital development for MSMEs, with particular focus on youth and women are among its priorities (ASEAN Secretariat, 2015b).

Women are deemed important part of a trade. They take part in a wide range of activities in the industry - produce products, commerce of goods across borders, run and own trading firms, and make up a large part of the workforce in export-oriented businesses. Nevertheless, women's potential and skills in trade is still too often held back by the many constraints ("Women must play a bigger", 2017).

Sen (2001) has identified seven varieties of disparities between genders: (1) mortality inequality; (2) natality inequality; (3) basic-facility inequality; (4) special-opportunity inequality; (5) professional inequality; (6) ownership inequality; and (7) household inequality. Mortality inequality directly tackles life and death, with women being observed to have high mortality rates than men on communities with documented gender-biased as compared to communities with little or no gender bias. Natality inequality is the preference for boys over girls, which is a characteristic of patriarchal societies. Basic-facility inequality, as the name suggests, are biases that involved basic needs such as equal opportunity to attend school and 
social functions. Special-opportunity inequality covers privileges such as access to higher education, training, and professional work, among others. Professional inequality covers those that pertain to promotion in work and occupation. Ownership inequality relates to biases in property ownership, which is identified to affect not only the voice of women in the society but also make it harder for women to enter and flourish in commercial, economic, and even in some social functions. Household inequality directly tackles the unequal distribution of household roles and responsibilities, which in some societies, is to take for granted that men will naturally work outside the home. In contrast, women could do so only if they could combine such work with various inescapable and unequally shared household duties.

Given these scenarios, the research explores the business environment for Filipino women involved in the micro, small and medium enterprises. It draws a comparison with select ASEAN countries, namely Singapore and Myanmar, using the available published resources. Specifically, the research aspires to determine the following:

1. Who are the women involved in the MSMEs?

2. What are the current policies, programs, and services designed for women in MSMEs?

3. What are the constraints and opportunities to enhance women's participation in MSMEs?

\section{LITERATURE REVIEW}

It has been noted that trade has become the lens through which development is perceived, rather than the other way around (Çağatay, 2005). Gonzalez and Grown (2015) conclude that women -as entrepreneurs, heads of households, and consumers, among other roles - are crucial to ending poverty and boosting global prosperity. In short, women are crucial to success in international trade.

Likewise, Adrianzen (2006) writes Karl Marx taught that anyone who knows something of history knows that the great social changes are impossible without the feminist ferment. He believes that social progress could be measured precisely by the social position of women. On the other hand, to Lenin, the participation of women is more much urgent and essential to the revolution in which the experience of all the liberation movements proves that the success of the revolution rests on the degree in which women are involved. In this case, the revolution is women's participation in trade (Adrianzen, 2006).

Singapore is ranked eighth on a list of cities worldwide for its ability to attract and foster the growth of women-owned firms. The research looks at the cities based on the impact of local policies, programs, and characteristics, along with national laws and customs, affecting the level of women-owned firms. The research ranks the cities across five critical aspects: capital, technology, talent, culture, and markets (Woo, 2017). 
Holzman and Roberts-Robbins (2019) note that women entrepreneurs face specific barriers when dealing with bureaucracy- therefore particularly salient in bureaucratic Myanmar. These challenges may arise from lower educational attainment, literacy levels, and underrepresentation of women in senior positions, e.g., legislators, senior officials, and managers, which an entrepreneur may contend with when formalizing and developing her business.

While Myanmar has a women-focused entrepreneur association and a tech startup sector seeking to encourage young female entrepreneurs, specifically women-focused acceleration programs are absent, in traditional sectors in particular, that seek to address entrepreneurship in a context tailored to specific challenges encountered by women and existing small businesses (Totten, Lwin \& van Roosmalen, 2019).

Asia Pacific Foundation of Canada (2018) finds that women entrepreneurs comprise $70 \%$ of total respondents with $39 \%$ founders and $31 \%$ non-founders. It is noted that the Philippines consistently ranks within the top 10 in the world for gender parity in political and business leaders and as a regional leader around gender parity in entrepreneurship, with women, recently overtaking men entering the entrepreneurial space.

The research further notes that men are significantly more likely to be looking for modest (52\%) to high (18\%) revenue growth for their companies than women are. In contrast, women are more likely to be inclined to no growth $(22 \%)$ or lower growth (18\%).

Existing structural barriers for women entrepreneurs and women-led MSMEs may influence how they interpret and articulate their ideas and ambitions of growth; frequently cited barriers include access to financing, security issues, social support and familial constraints, and lack of access to technology and relevant skills training. Studies show that gender equality has a positive impact on economic growth. However, research that explores the effects of economic growth on gender equality is less consistent. Only $8 \%$ of survey respondents are aiming for high revenue growth. Mostly younger male respondents (under 35 years old) and male respondents tend to be more ambitious than their counterparts are.

Figure 1 presents the conceptual framework that the research has adopted serving as a guide in the conduct of the research and its structure. 


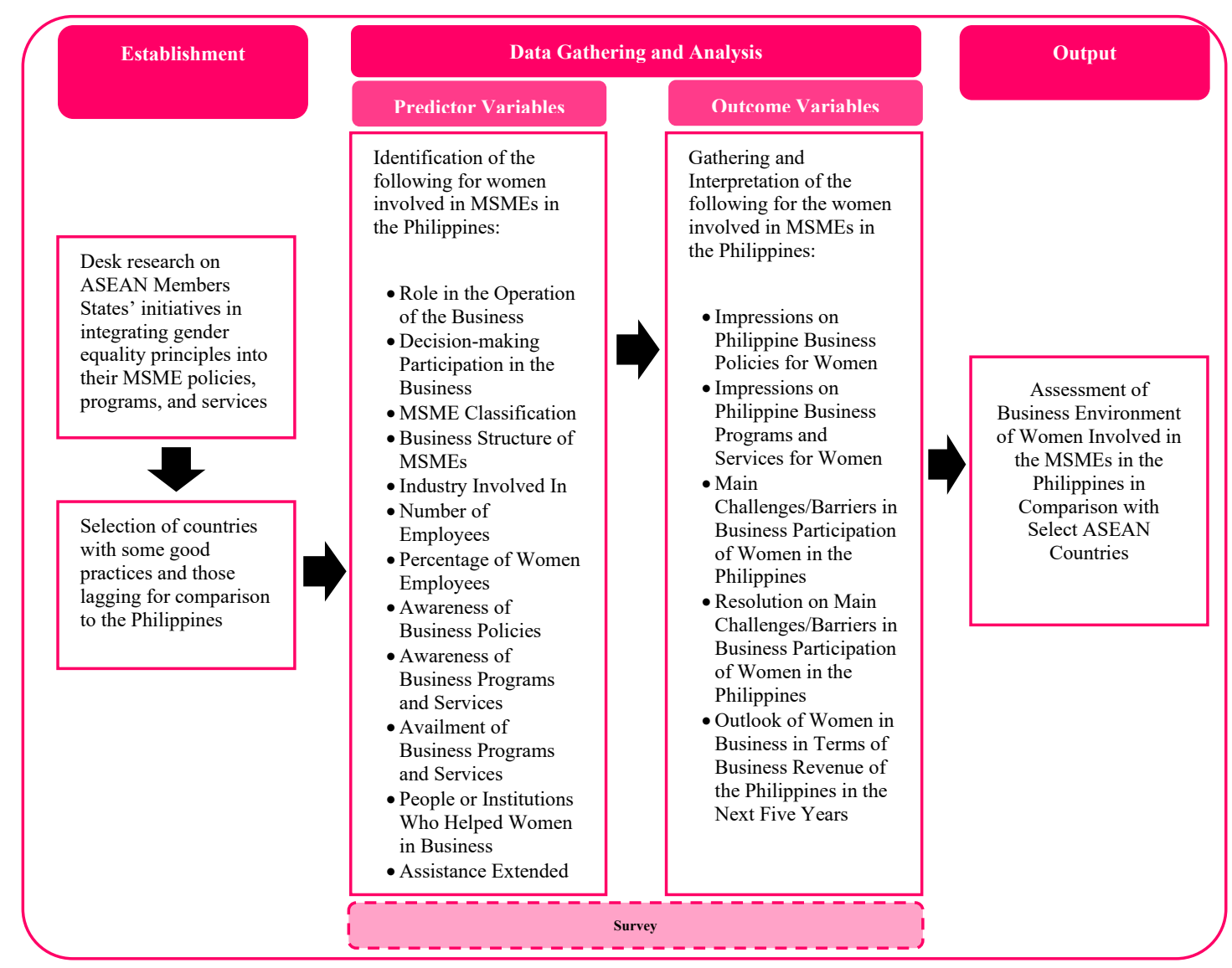

Figure 1 Conceptual Framework

\section{RESEARCH METHODS}

The selection of countries is based on their extent of integrating gender equality principles into their MSME policies, programs, and services. Specifically, those with some good practices and on the other extreme those lagging are chosen as target groups. The similarities and differences among these countries are identified and explored in the research.

The research collects and analyses secondary quantitative and qualitative data. It uses an online (internet) survey. Primary data are gathered through purposive sampling using the available list of MSMEs requested from the Department of Trade and Industry (DTI). The said list has 573 MSMEs, but only 5\% is able to answer the questionnaire. The survey is conducted within one month from March 18, 2020 to April 18, 2020 at a time the world is experiencing a pandemic due to Coronavirus Disease (COVID-19).

\section{ANALYSIS}

\section{ASEAN Business Environment for Women}

The ASEAN Small and Medium-Sized Enterprises (SME) Policy Index 2018: Boosting Competitiveness and Inclusive Growth presents an analysis of the progress of the ASEAN 
Member States (AMS) in terms of achieving the objectives of the ASEAN Strategic Action Plan for SME Development 2016-2025.

The SME Policy Index serves as a benchmarking tool for assessing SME policy frameworks in emerging economies and monitor progress in policy implementation using indicators over time. The Index was developed in 2006 by the Organisation for Economic Cooperation and Development (OECD) in collaboration with the European Commission, the European Bank for Reconstruction and Development (EBRD), and the European Training Foundation (ETF) since SME has been recognized as a vital part of economic development across the globe (OECD GRS Southeast Europe Division and Eurasia Division, 2014).

Based on Table 1 that shows score on inclusive entrepreneurship for women, the Philippines is rated the highest with 4,90 on the scale of 1 to 6 , with 6 being the highest, while Myanmar is rated the least with 1,82 .

Table 1. Comparative SME Policy Index Score on Inclusive Entrepreneurship for Women

\begin{tabular}{|l|c|c|c|c|c|c|c|c|c|c|c|c|}
\hline Para-meters & BRN & KHM & IDN & LAO & MYA & MMR & PHL & SGP & THA & VNM & MED & StD. \\
\hline $\begin{array}{l}\text { Planning and } \\
\text { design }\end{array}$ & 2,00 & 4,42 & 3,74 & 2,91 & 3,82 & 2,25 & 6,00 & 4,25 & 3,08 & 3,49 & $\mathbf{3 , 6 2}$ & $\mathbf{1 , 1 0}$ \\
\hline $\begin{array}{l}\text { Implemen- } \\
\text { tation }\end{array}$ & 2,19 & 2,55 & 3,34 & 2,66 & 5,10 & 1,86 & 4,44 & 4,66 & 2,61 & 2,27 & $\mathbf{2 , 6 3}$ & $\mathbf{1 , 1 0}$ \\
\hline $\begin{array}{l}\text { Monitoring and } \\
\text { evaluation }\end{array}$ & 1,83 & 1,83 & 1,83 & 1,28 & 2,93 & 1,00 & 4,04 & 3,77 & 1,55 & 1,55 & $\mathbf{1 , 8 3}$ & $\mathbf{1 , 0 0}$ \\
\hline $\begin{array}{l}\text { Total sub- } \\
\text { dimension } \\
\text { score }\end{array}$ & $\mathbf{2 , 0 5}$ & $\mathbf{3 , 0 6}$ & $\mathbf{3 , 1 8}$ & $\mathbf{2 , 4 7}$ & $\mathbf{4 , 2 2}$ & $\mathbf{1 , 8 2}$ & $\mathbf{4 , 9 0}$ & $\mathbf{4 , 3 4}$ & $\mathbf{2 , 5 6}$ & $\mathbf{2 , 5 5}$ & $\mathbf{2 , 8 1}$ & $\mathbf{0 , 9 9}$ \\
\hline
\end{tabular}

Note: Scores are on a scale of 1 to 6, with 6 being the highest.

Source: OECD, ASEAN SME Policy Index 2018

Furthermore, the ASEAN SME Policy Index 2018 notes that among the AMS, the Philippines and Vietnam are the only countries with SME strategy documents with specific strategies for women entrepreneurs. In Singapore, there is no particular strategy for women entrepreneurs as barriers have been assessed to be very low (OECD, 2018).

\section{Singapore: SMEs the Heart of Economy}

In 2018, the Singapore Department of Statistics presented that SMEs form $99 \%$ of the total enterprises and generate almost $69 \%$ of total employment in Singapore. Indeed, SMEs are the heart of Singapore's economy (Table 2 and Table 3 ). 
Table 2. 2018 Estimates by Enterprise Classification in Singapore

\begin{tabular}{|c|c|}
\hline \multicolumn{1}{|c|}{ Variables } & Count \\
\hline Enterprises Count, Total (Thousand) & $\mathbf{2 6 3 , 9}$ \\
\hline Enterprises Count, SMEs (Thousand) & 262,6 \\
\hline Enterprises Count, Non-SMEs (Thousand) & 1,3 \\
\hline Employment of Enterprises, Total (Million) & $\mathbf{3 , 5}$ \\
\hline Employment of Enterprises, SMEs (Million) & 2,5 \\
\hline Employment of Enterprises, Non-SMEs (Million) & 1 \\
\hline
\end{tabular}

Source: Singapore Department of Statistics, M600981- Topline Estimates

for All Enterprises and SMEs, Annual 2018

Table 3. 2018 Estimates by Ownership for All Enterprises in Singapore

\begin{tabular}{|c|c|}
\hline \multicolumn{1}{|c|}{ Variables } & Count \\
\hline Enterprises Count, Total (Thousand) & $\mathbf{2 6 3 , 9}$ \\
\hline Enterprises Count, Total Local (Thousand) & 217,6 \\
\hline Enterprises Count, Total Foreign (Thousand) & 46,3 \\
\hline Employment of Enterprises, Total (Million) & $\mathbf{3 , 5}$ \\
\hline Employment of Enterprises, Total Local (Million) & 2,4 \\
\hline Employment of Enterprises, Total Foreign (Million) & 1,1 \\
\hline
\end{tabular}

Source: Singapore Department of Statistics, M601511- Topline Estimates by Ownership for All Enterprises, Annual 2018

Enterprise Singapore is the lead government agency supporting enterprise development. They focus on building capabilities, innovation, and internalization of committed companies. Enterprise Singapore is a fusion of previously two separate entities: International Enterprise (IE) Singapore and Standards, and Productivity and Innovation Board (SPRING) Singapore, which merged on April 1, 2018 (Enterprise Singapore, 2019).

Enterprise Singapore offers a wide range of assistance for MSMEs. Among them, financial assistance, market access, and talent assistance are the most popular, as seen in Table 4.

Table 4. Popular Assistance under Enterprise Singapore

\begin{tabular}{|l|l|l|l|l|}
\hline Area & \multicolumn{1}{|c|}{$\begin{array}{c}\text { Double Tax } \\
\text { Deduction for } \\
\text { Internationalisation } \\
\text { (DTDi) }\end{array}$} & $\begin{array}{c}\text { Market Readiness } \\
\text { Assistance (MRA) } \\
\text { Grant }\end{array}$ & $\begin{array}{c}\text { Enterprise } \\
\text { Development Grant }\end{array}$ & $\begin{array}{c}\text { International } \\
\text { Marketing } \\
\text { Activities } \\
\text { Programme } \\
\text { (iMAP) }\end{array}$ \\
\hline $\begin{array}{l}\text { Financial } \\
\text { Assistance }\end{array}$ & $\begin{array}{l}\text { Companies planning } \\
\text { to expand overseas } \\
\text { can benefit from the } \\
\text { Double Tax } \\
\text { Deduction Scheme } \\
\text { for } \\
\text { Internationalisation }\end{array}$ & $\begin{array}{l}\text { Small and medium } \\
\text { enterprises (SMEs) } \\
\text { will receive an } \\
\text { international boost } \\
\text { with the Market } \\
\text { Readiness Assistance } \\
\text { (MRA) grant to help }\end{array}$ & $\begin{array}{l}\text { The Enterprise } \\
\text { Development Grant } \\
\text { (EDG) helps } \\
\text { Singapore companies } \\
\text { grow and transform. } \\
\text { This grant supports } \\
\text { projects that help }\end{array}$ & $\begin{array}{l}\text { Companies } \\
\text { participating in } \\
\text { iMAP approved } \\
\text { activities will } \\
\text { receive a support of } \\
\text { up to 50\% or 70\% } \\
\text { of eligible core }\end{array}$ \\
\hline
\end{tabular}




\begin{tabular}{|c|c|c|c|c|}
\hline \multirow[t]{2}{*}{ Area } & \multicolumn{4}{|c|}{ Assistance } \\
\hline & $\begin{array}{l}\text { (DTDi), with a } 200 \% \\
\text { tax deduction on } \\
\text { eligible expenses for } \\
\text { international market } \\
\text { expansion and } \\
\text { investment } \\
\text { development } \\
\text { activities. }\end{array}$ & $\begin{array}{l}\text { take their business } \\
\text { overseas. }\end{array}$ & $\begin{array}{l}\text { enterprises upgrade } \\
\text { their business, } \\
\text { innovate or venture } \\
\text { overseas, under three } \\
\text { pillars: Core } \\
\text { Capabilities, } \\
\text { Innovation and } \\
\text { Productivity, and } \\
\text { Market Access. }\end{array}$ & $\begin{array}{l}\text { expenses } \\
\text { (depending on } \\
\text { which country the } \\
\text { event is held in)- } \\
\text { including exhibition } \\
\text { rental space, booth } \\
\text { construction, } \\
\text { publicity, and fair or } \\
\text { mission consultancy } \\
\text { costs. }\end{array}$ \\
\hline \multirow[b]{2}{*}{$\begin{array}{l}\text { Market } \\
\text { Access }\end{array}$} & $\begin{array}{c}\text { Free Trade } \\
\text { Agreement (FTA) } \\
\text { Portal }\end{array}$ & $\begin{array}{l}\text { Plug \& Play } \\
\text { Network }\end{array}$ & & \\
\hline & $\begin{array}{l}\text { Find a simpler way to } \\
\text { do business } \\
\text { internationally with } \\
\text { Singapore's network } \\
\text { of } 20 \text { FTAs. }\end{array}$ & $\begin{array}{l}\text { Speed up the entry } \\
\text { into overseas markets } \\
\text { with key information } \\
\text { like specific trade } \\
\text { regulations, import } \\
\text { procedures, detailed } \\
\text { competitor analysis, } \\
\text { and customized } \\
\text { market research } \\
\text { reports tailored to } \\
\text { enterprise products } \\
\text { and services. }\end{array}$ & & \\
\hline \multirow[b]{2}{*}{$\begin{array}{l}\text { Talent } \\
\text { Assistance }\end{array}$} & $\begin{array}{c}\text { Overseas Market } \\
\text { Workshop }\end{array}$ & $\begin{array}{l}\text { China Ready } \\
\text { Programme }\end{array}$ & $\begin{array}{c}\text { Professional } \\
\text { Conversion } \\
\text { Programme (PCP) - } \\
\text { International } \\
\text { Trading } \\
\end{array}$ & $\begin{array}{l}\text { International } \\
\text { Trading Track } \\
\text { (ITT@SMU) }\end{array}$ \\
\hline & $\begin{array}{l}\text { The Overseas Market } \\
\text { Workshop helps } \\
\text { individuals build } \\
\text { regional market } \\
\text { understanding } \\
\text { through knowledge } \\
\text { sharing by local and } \\
\text { foreign practitioners, } \\
\text { business owners, and } \\
\text { market experts. }\end{array}$ & $\begin{array}{l}\text { These in-market } \\
\text { programs help } \\
\text { participants gain first- } \\
\text { hand knowledge of } \\
\text { China's business } \\
\text { environment, } \\
\text { including market } \\
\text { insights, culture, and } \\
\text { financial systems. }\end{array}$ & $\begin{array}{l}\text { The International } \\
\text { Trading PCP aims to } \\
\text { develop Singaporeans } \\
\text { with deep skills in } \\
\text { trading fundamentals } \\
\text { for international job } \\
\text { roles in middle office } \\
\text { functions. }\end{array}$ & $\begin{array}{l}\text { ITT@SMU } \\
\text { develops talent at } \\
\text { both the undergrad } \\
\text { and graduate levels } \\
\text { for companies in the } \\
\text { commodity trading } \\
\text { sector. }\end{array}$ \\
\hline
\end{tabular}

Source: Enterprise Singapore, 2019

The Mastercard Index of Women Entrepreneurs (MIWE) 2018 lists Singapore as the fifth best country with the most robust supporting conditions and opportunities for women to thrive as entrepreneurs. The Index ranks the countries based on three components. The first one is the level of Women's Advancement Outcomes, which include degree of preference against women as workforce participants, political and business leaders, and their financial strength and entrepreneurial inclination). Secondly, it is their Knowledge Assets and Financial Access including degree of access to a basic financial facility, advanced knowledge assets, and support for SMEs of women. The last one is Supporting Entrepreneurial Factors, which involves overall perceptions on the ease on conducting business locally, quality of local governance, women's understanding of safety levels and cultural knowledge of women's household financial influence. The Index uses 12 indicators and 25 sub-indicators to assess how 57 countries across the Asia Pacific, Middle East \& Africa, North America, Latin 
America, and Europe, which constitutes $78,6 \%$ of the world's female labor force, differ in terms of their level on the three components mentioned earlier. Moreover, women in Singapore topped the rankings at $90,9 \%$ in terms of knowledge assets and financial access. Singapore also offers one of the most conducive conditions to encourage women business ownership, such as ease of doing business and cultural opinions of women as entrepreneurs.

However, the report also shows that the rank of Singapore dropped from the third place in 2017 as its overall score fell from 71,2 to 69,2 in 2018 , recording a $3 \%$ decrease. The research points out that the Singapore's rank drop is attributed to the decline in the proportion of female entrepreneurs compared to males, which is $61,9 \%$ in 2017 and 48,3 percent in 2018. The report also cites that only $27 \%$ of business owners are women, which put Singapore to $14^{\text {th }}$ place - a drop from its 2017 rank at $12^{\text {th }}$ place. The Index also notes that Singaporean Women entrepreneurs have also not progressed much as their rankings in the advancement outcomes component fell eight spots to $39^{\text {th }}$ with a score of $49,4(-6 \%)$. The research mentions reasons such as the less healthy representation of women business owners and low entrepreneurial activity rate as the reasons for the decline (MasterCard, 2019).

\section{Myanmar: SMEs are the Backbone of the Economy}

OECD (2013) reports that there are about 126,237 formally registered enterprises in Myanmar, which constitutes $99,4 \%$ of the total businesses (see Table 5)

Table 5. Number of Establishments per Classification in Myanmar

\begin{tabular}{|l|c|c|}
\hline \multicolumn{1}{|c|}{ Establishments } & Number & Percentage \\
\hline Small and medium enterprises & 126.237 & $99,4 \%$ \\
\hline Large enterprises & 721 & $0,6 \%$ \\
\hline Total & $\mathbf{1 2 6 . 9 5 8}$ & $\mathbf{1 0 0 \%}$ \\
\hline
\end{tabular}

It is furtherly noted that the relatively low number of SMEs is due to: (1) weak entrepreneurship culture; (2) a lack of incentives to enter the formal sector; (3) a remaining influence of the centrally planned economic system; and (4) the important role of state-owned enterprises in the market Myanmar (OECD, 2013).

The Statement of Economic Policy of the Union of Myanmar, which was released on $29^{\text {th }}$ July 2016, underscores the government's focus on its people and desire to achieve inclusive and continuous development. The 12-point economic policy endeavors to establish an economic framework that supports national reconciliation, based on the fair distribution, mobilization, and allocation of sustainable natural resources across the States and Regions.

The government's 12- point economic policy targets explicitly support for SMEs, aiming to improve access to credit and financial services. The economic policy also intends to address challenges in doing business in the country. Supportively, the Ministry of Industry (MoI) aims to draft a new SME development strategy, which will focus on infrastructure development, technology transfer, and soft lending programs. With the government and 
international lenders working together in recent years to boost credit, safeguarding a reliable source of affordable loans to small businesses will be critical for long-term policy goals. The current SME Development Policy in force was drafted in 2015 and envisioned to stimulate the development of SMEs across all sectors, which are competitive and innovative. These sectors are perceived to enhance income generation and contribute to socio-economic development. Furthermore, the key priority areas of the 2015 SME Development Policy are (1) human resource, (2) technology development and innovation, (3) financial resource, (4) infrastructure development, (5) market access, (6) appropriate taxation and procedures, and (7) conducive business environment (DOCA of Myanmar, 2015).

OECD (2018) reports that Myanmar does not currently have a working strategy for SME development in place. Instead, the 2015 SME Development Policy serves as a general policy for SME development, which marked an improvement from the 2014 assessment. It is furtherly noted that there are very little monitoring and evaluation of policies and programs for SMEs (OECD, 2018).

The Myanmar SME Development Agency, which was established in April 2012, provides support assistance for MSMEs through trade fairs and competitions, awarding the National MSMEs award, technology transfer, business matching and exhibitions, capacity building, financial access, SMEs registration, and advisory and consulting service (Myanmar SME Development Agency, 2020).

The Framework for Economic and Social Reform (FESR) and the Comprehensive National Development Plan (2012-2015) has developed in collaboration with senior officials of various ministries and departments of the government from May to October 2012. This is in line with President U Thein Sein's announcement of the second stage of reforms after politically liberalizing measures has been introduced. The FESR has laid out policy priorities for the government in the next three years while outlining key parameters of the reform process that will enable Myanmar to become a modern, developed, and democratic nation by 2030 . Specifically, for women, the FESR mentions the following: (1) embracing worker's rights and social protection ensuring rights-based, inclusive and systemic policy development, with due attention given to alleviating poverty and addressing inequities, social exclusion, and emergencies; (2) prevention of violence against women and trafficking in persons; (3) promotion of gender equality and women empowerment; and (4) improvement of maternal health (MDRI-CESD, 2012).

The Ministry of Social Welfare, Relief and Resettlement launched the National Strategic Plan on the Advancement of Women (2013-2022) in 2013. The ten-year National Strategic Plan covers the key areas that affect women's lives and present practical ways to address the issues that Myanmar women are experiencing. The plan is based on the 12 priority areas outlined in the Beijing Platform for Action and the principles of the convention on the Elimination of All Forms of Discrimination against Women (CEDAW) to which Myanmar became a signatory in 1997. The 12 priority areas covered are: (1) Women and Livelihoods, (2) Women, Education, and Training, (3) Women and Health, (4) Violence Against Women, (5) Women and Emergencies, (6) Women and the Economy, (7) Women and Decision-Making, 
(8) Institutional Mechanisms for the Advancement of Women, (9) Women and Human Rights, (10) Women and the Media, (11) Women and the Environment, and (12) The Girl Child. Focusing on priority number 1 and 6, Women and Livelihoods and Women and the Economy, the plan aims to cultivate enabling systems, structures, and practices that improve women's livelihoods and reduce poverty and to strengthen mechanism, framework, and practices to uphold fairness and equal rights for women concerning employment credit, resources, assets and economic benefits (MoSWRR, 2012).

The International Labor Organization (ILO) (2014) on its National Assessment of Women's Entrepreneurship Development in Myanmar notes that although the Government of Myanmar publishes some official data on MSMEs, it does not contain sex-disaggregated data on the percentage of enterprises owned by women. On the other hand, the data on selfemployment from the 2014 Population and Housing Census reveals that $37,7 \%$ of employed women are self-employed, in contrast with $47,3 \%$ of employed men. It shows that there are an estimated 3,3 million self-employed women and 6,4 million men in Myanmar, and men are almost twice as likely to be self-employed. Women in Myanmar comprises the estimated 34\% of own-account self-employed persons (excluding employees) in the country, but only 25,6\% of employers. The ILO notes that this might entail that women hurdle more challenges in developing their microenterprises into small- and medium-sized enterprises, and in producing more jobs (ILO, 2014).

\section{Philippine MSMEs as Economic Drivers}

The Philippine Statistics Authority (PSA) in 2018 recorded a total of 1.003 .111 establishments in 2018 of which 998.342 or $99,52 \%$ are MSMEs. Microenterprises account for $88,45 \%$ (887.272), small enterprises for 10,58\% (106.175), and medium enterprise for $0,49 \%$ (4.895). On the other hand, large enterprises account for only $0,48 \%$ (4.769) of the total establishments, as seen in Figure 2.

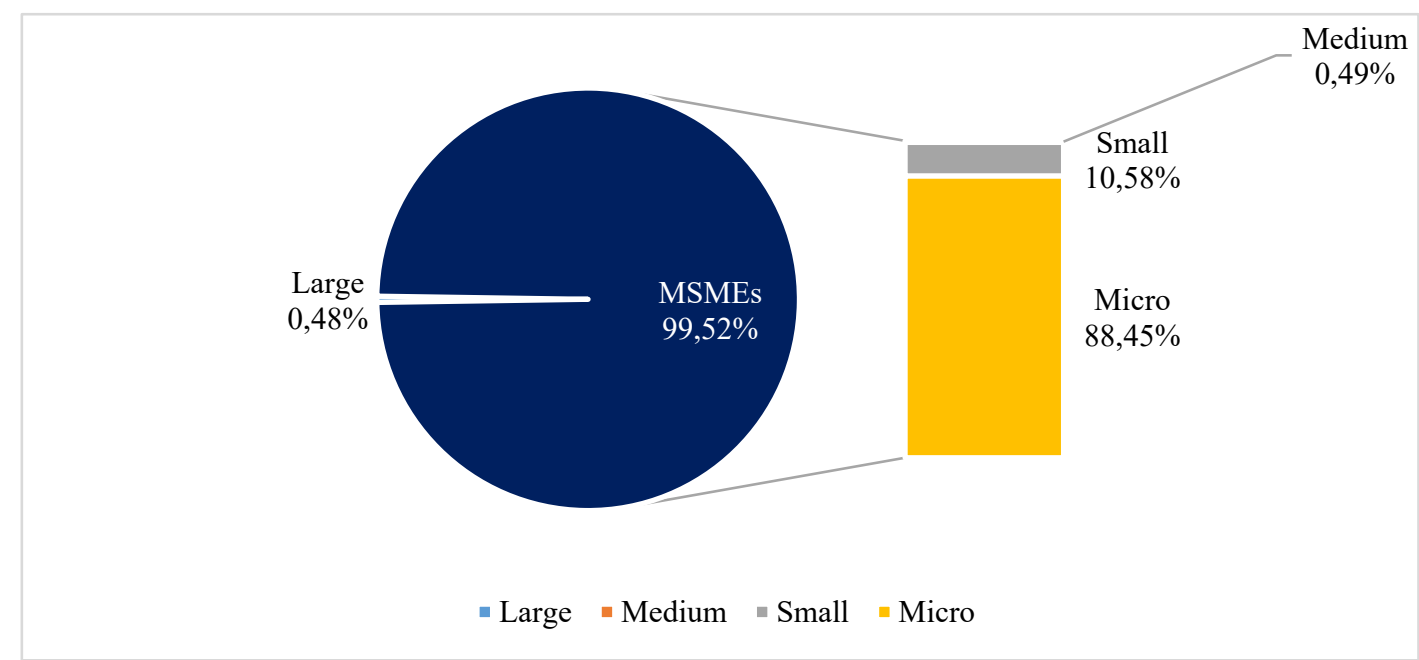

Figure 2. 2018 Number of Establishments per Classification in the Philippines

Source: Philippine Statistics Authority (PSA), Number of Establishments by Section and Employment Groupings (MSMEs), Philippines: 2018 LE 
In Figure 3, it can been that although large companies constitute the least number of establishments, they employs $37 \%$ of the total workforce of enterprises. Microenterprises comprise $29 \%$ of the employment, small enterprises with $27 \%$, and medium enterprises with 7\% (PSA, 2018).

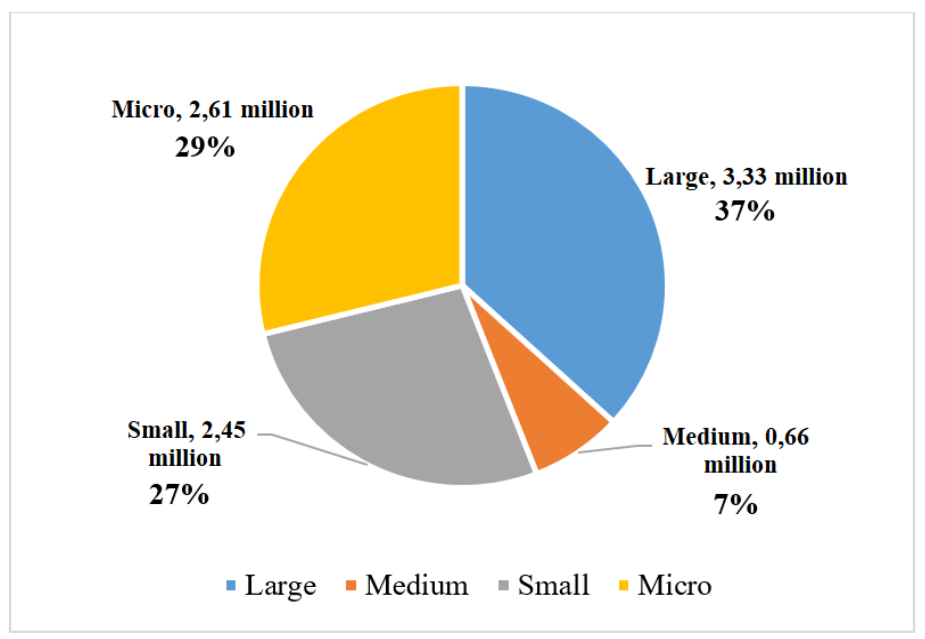

Figure 3. 2018 Employment per Establishment Classification in the Philippines

Source: Philippine Statistics Authority (PSA), Total Employment by Section and Employment Groupings (MSMEs), Philippines: 2018 LE

In the Philippines, the Bureau of Small and Medium Enterprises (BSMED) of the Department of Trade and Industry (DTI) acts as the Secretariat of the Micro, Small and Medium Enterprise Development (MSMED) Council, as stipulated on Republic Act (RA) No. 6977, or the Magna Carta for MSMEs. BSMED develops and implements programs and projects that address the specific needs of MSMEs. These programs and projects cover the areas of technology development and transfer, financing, marketing, and training. The BMSMED is also mandated to promote and develop MSMEs in the country and is also tasked to assess and proposed policies and strategies geared towards the advancement of MSMEs in the areas of entrepreneurship development, institutional strengthening, and productivity improvement.

According to MSMED Plan 2017-2022, government policies and programs for MSMEs encompass the following four outcome areas such as Business Environment, Productivity and Efficiency, Market Access, and Access to Finance.

Business Environment refers to a dynamic practice and culture of governance that fosters the establishment, development, sustainability, and competitiveness of socially responsible and environment-friendly MSMEs. Supportively, the outcome area on the policy side are: 1) Republic Act (RA) No. 9501: Magna Carta for Micro, Small and Medium Enterprises; 2) RA No. 6977, as amended by RA No. 8289; 3) RA No. 9178: Barangay Micro Business Enterprises (BMBEs) Act of 2002; 4) RA 10644: Go Negosyo Act; 5) RA 10679: Youth Entrepreneurship Act; 6) RA No. 9485: Anti-Red Tape Act; 7) DTI-DILG Joint Memorandum Circular No. 1 Series of 2011: Guidelines in Implementing the Standards in 
Processing Business Permits and Licenses in All Cities and Municipalities; and 8) DTI-DILG Joint Memorandum Circular No.1 Series of 2016: Revised Standards in Processing Business Permits and Licenses in All Cities and Municipalities.

On January 24, 1991, the Philippines passed RA No. 6977: An Act to Promote, Develop and Assist Small and Medium Scale Enterprises through the Creation of a Small and Medium Enterprise Development (SMED) Council, and the Rationalization of Government Assistance Programs and Agencies Concerned with the Development. RA No. 6777 is also known as the Magna Carta for Small Enterprises. The act recognizes that SMEs have the potential for more employment generation and economic growth and, therefore, can contribute to a self-sufficient industrial foundation for the country. RA No. 6777 has been declared the policy of the State to promote, support, strengthen, and encourage the growth and development of SMEs in all productive sectors of the economy, particularly rural or agri-based enterprises. The law was amended on May 6, 1997 as RA No. 8289: An Act to Strengthen the Promotion and Development of, and Assistance to Small and Medium Scale Enterprises (SMEs). The law was further amended on May 23, 2008 as RA 9501: An Act to Promote Entrepreneurship by Strengthening Development and Assistance Programs to Micro, Small and Medium Scale Enterprises (MSMEs), otherwise known as the Magna Carta for MSMEs. According to the declaration of the policy, the law recognizes that MSMEs have the potential for more employment generation and economic growth and thus can help provide a self-sufficient industrial foundation for the country. Hence it has been declared as the policy of the State to assist, promote, strengthen, and foster the growth and development of MSMEs in all productive sectors of the economy to include rural or agri-based enterprises. Given this, the State shall recognize the specific needs of the MSMEs, and the particular needs of the MSMEs and shall undertake to promote entrepreneurship, support entrepreneurs, encourage the establishments of MSMEs and ensure their sustainability and growth to attain countryside industrialization.

RA No. 9178: An Act to Promote the Establishment of Barangay Micro Business Enterprises (BMBEs), otherwise known as the Barangay Micro Business Enterprises (BMBEs) Act of 2002 was signed into law on November 13, 2002. The law was declared as a policy to hasten the country's economic development by boosting the establishment and growth of barangay microenterprises, which effectively serve as an avenue for the development of Filipino entrepreneurial talents. The law endeavors to integrate those in the informal sector with the mainstream economy through the rationalization of bureaucratic limitations, the active intervention of the government, especially at the local or grassroots level, and the granting of incentives, benefits, and assistance to generate much-needed employment and alleviate poverty.

RA No. 9178 classifies BMBE as any business enterprise engaged in production, processing, or manufacturing of products, which includes agro-processing, as well as trading and services. BMBE has a total asset of not more than PhP 3 millions, which consists of those that arise from loans but not the land on which the plant and equipment are located. RA No. 9178 excludes in the services provided by anyone who is licensed by the government after having passed a licensure examination, in connection with the exercise of one's profession (e.g., Accountant, Lawyer, Doctor, etc.). The Department of Finance's (DOF's) Department 
Order (DO) No. 17-04 states that an enterprise could only qualify to register as a BMBE if it is not a branch, subsidiary, division or office of a large enterprise and its policies and business operations are not managed by large enterprises or by persons who are neither owners nor employees of the enterprise (i.e., franchises).

RA No. 9178 primarily aims to integrate micro-enterprises in the informal sector into the mainstream of the economy. Reinforcing active participation of BMBEs in the economy would mean more jobs and livelihood, and a better quality of life for Filipinos. Furthermore, under RA No. 9178, BMBEs are qualified for income tax exemption from income arising from the operations of the enterprise. Exclusion from the coverage of the Minimum Wage Law with employees assures to receive the same social security and health care benefits as other employees in any other enterprise classification, priority to a special credit window set up specifically for the financing needs of BMBEs, and technology transfer, production, management training, and marketing assistance programs for BMBE beneficiaries.

RA No. 10644: An Act Promoting Job Generation and Inclusive Growth through the Development of Micro, Small and Medium Enterprises, known as the Go Negosyo Act was signed into law on July 15 2014. It is to promote national development, encourage inclusive growth, and reduce poverty by encouraging the establishment of micro, small and medium enterprises (MSMEs) that facilitate local job creation, production and trade in the country. The law aims for: 1) the establishment of Negosyo Centers in all provinces, cities, and municipalities Nationwide; 2) MSMEs Development Fund and BMBE Fund supported the establishment of a Start-up Fund; 3) transfer of technology, training related to production and management, and marketing assistance for SMEs; 4) a unified and simplified business registration through automatic approval of business permits and licenses that were declined for any reason within 15 days; and 5) reconfiguration of the MSME Development Council and its additional functions.

RA No. 10679: An Act Promoting Entrepreneurship and Financial Education Among Filipino Youth, known as the Youth Entrepreneurship Act was signed into law on August 27, 2015 to promote the enduring development of young Filipinos with aptitude and skill in the field of finance and entrepreneurship. RA No. 10679 encourages and endeavor to hone the youths' skills through education and specialized training programs. Given this, the State is directed to establish, maintain, and support a complete, adequate, and integrated system of education and training to boost the entrepreneurial spirit among youth as well as boost and foster the growth of young entrepreneurs nationwide. The law endeavors to integrate entrepreneurship into the Philippines' secondary and tertiary education curricula, facilitate grants for both the teaching and the practice of entrepreneurship, and develop a national youth entrepreneurship program to provide support to young entrepreneurs. The Philippines has various programs and services to support MSMEs. These are reflected in the MSMED Plan 2017-2022. The programs and services are divided into Productivity and Efficiency, Market Access, and Access to Finance. 


\section{Results of the Survey Conducted with Women Involved in Micro, Small, and Medium Enterprises (MSMEs) in the Philippines}

Women-led MSMEs usually deal with challenges such as social and cultural norms, gender stereotypes, lack of access to decision-making, unequal access to resources, lack of access to education or training, which significantly constrain business opportunities. Not to mention they encounter problems like limited access to finance, information and communication technology (ICT) and a lack of market information, as well as burdensome regulations and administrative procedures (UNESCAP, 2017).

Focusing on the Philippines, respondents are all part of the C-Level executives of companies, if not the owners. They also participate in decision-making for the companies. The participation of women in the workforce pool is also comparable with that of men. These are good indications of the attitude of the Philippines in terms of women's participation in leadership.

Respondents shows a high desire to contribute economically through business as most of the respondents are driven by the aspiration to provide livelihood or employment, to fill the gap in the market, as well as to support and provide for the needs of their families. Engaging in business has been their avenue for a sense of achievement and to support advocacy for the industry.

Respondents convey fulfillment in doing business in the Philippines. However, they also express a need to streamline governmental requirements and procedures and services and the need for government incentives to support businesses led by women, among others.

Although the majority believe that they feel empowered to engage in economic activity in the Philippines, it remains difficult for a woman to enter into a business. This is primarily because they consider the programs and services need to be more accessible for them. Not to mention there is still a constant struggle to prove themselves in terms of their capabilities to run a business as compared to their male counterpart. As for policies and programs supporting women in terms of business, the majority of them are not aware of any. For those who are aware, they believe that these policies and programs are in place to empower them, prevent discrimination in all forms, protect them from abuse, and help them access wider opportunities, improve their business, among others. However, others deem that programs and services for women need improvements. Most of them also do not avail of any programs and services for women.

Respondents consider a lack of financial support or resources as their primary barriers to engaging in the business. They also mention that in spite of empowerment to run a business, there are still instances when they feel discriminated against. Slow government transactions are also one of the bottlenecks. For those dealing with food manufacturing, they mention hurdles with transactions at the Food and Drug Administration (FDA). Gaining various certifications to gain credibility such as Halal and Good Manufacturing Practices (GMP), among others, is also mentioned particularly that it also entails operational cost from them. Furthermore, women also feel the pressure in balancing running a business and family rearing. 
Despite challenges, respondents have optimistic views of the future in so far as their businesses are concerned, which is attributed to anticipation of more business opportunities, an expectation of a better operational organization, development and release of innovative products which answer the demand in the market, impact of technological advancement, and heightened collaboration between private and government entities. On the other hand, some respondents also convey anxiety on the impact of the global health crisis brought about by COVID-19 on the overall health of economy and business.

\section{CONCLUSIONS}

The research presents that women's participation in economic activity, in particular in MSMEs, is primarily affected by conditions that can catalyze engagements. Table 6 summarizes the various aspects of business environment that cover the degree of women's participation, policies, programs, and services for women in Singapore, Myanmar, and the Philippines.

Table 6 Comparative Table for the Business Environment Studied for Singapore, Myanmar, and the Philippines ${ }^{1}$

\begin{tabular}{|c|c|c|c|}
\hline Metrics & Singapore & Myanmar & Philippines \\
\hline $\begin{array}{l}\text { Profile of Women in } \\
\text { MSMEs }\end{array}$ & $27 \%$ are owners & $25.5 \%$ are employers & $56 \%$ are owners \\
\hline $\begin{array}{l}\text { Policies for Women in } \\
\text { MSMEs }\end{array}$ & $\begin{array}{ll}\text { No specific policies for } \\
\text { women but existing } \\
\text { policies are supportive of } \\
\text { women's business } \\
\text { ownership. }\end{array}$ & $\begin{array}{l}\text { Follows the } 2015 \text { SME } \\
\text { Development Policy } \\
\text { with (1) human resource, } \\
\text { (2) technology } \\
\text { development and } \\
\text { innovation, (3) financial } \\
\text { resource, } \\
\text { infrastructure } \\
\text { development, (5) market } \\
\text { access, (6) appropriate } \\
\text { taxation and procedures, } \\
\text { and (7) conducive } \\
\text { business environment as } \\
\text { key priority areas }\end{array}$ & $\begin{array}{l}\text { RA 9710: Magna Carta } \\
\text { of Women }\end{array}$ \\
\hline $\begin{array}{l}\text { Programs and Services } \\
\text { for Women in MSMEs }\end{array}$ & $\begin{array}{l}\text { Handled by } \\
\text { Singapore, } \\
\text { encompasses assistance } \\
\text { such as } \\
\text { assistance, financial } \\
\text { access, and talent } \\
\text { assistance for all } \\
\text { MSMEs. No specific } \\
\text { assistance for women. }\end{array}$ & $\begin{array}{l}\text { Led by the Myanmar } \\
\text { SME Development } \\
\text { Agency, which provides } \\
\text { capacity building, } \\
\text { technology promotion, } \\
\text { market promotion, and } \\
\text { business matching, } \\
\text { among others. No } \\
\text { specific programs and } \\
\text { services for women. }\end{array}$ & $\begin{array}{l}\text { Various programs and } \\
\text { services to support } \\
\text { MSMEs are reflected in } \\
\text { the MSMED Plan 2017- } \\
2022 \text {. There are } \\
\text { programs specific to } \\
\text { women such as GREAT } \\
\text { Women Project and } \\
\text { Spark! Philippines } \\
(2020) .\end{array}$ \\
\hline
\end{tabular}

${ }^{1}$ Information for Singapore and Myanmar was based on available secondary sources while for the Philippines was based on both primary (survey) and secondary sources. 
Singapore is said to have a conducive environment for women to engage in business. However, only less than one-third of business owners are women. This can be attributed to other considerations such as their societal responsibilities and motivation, among others, which can also be explored in future studies.

Myanmar Government lacks sex-disaggregated data for business owners, but according to their Ministry of Immigration and Population, there are only 25,6\% of employers. It can be gleaned from this situation that women encounter challenges in growing their businesses and, therefore, to create jobs. The current SME Development Policy, programs, and services should be reviewed to make these more relevant to the current needs of the MSMEs and, more importantly of women entrepreneurs and would-be entrepreneurs. Therefore, laying out a framework for monitoring and evaluation of the implementation of the current policies, programs, and services is deemed a must.

On the other hand, the majority of Filipino women entrepreneurs feel that they are empowered to run a business in the Philippines. However, challenges still affect the management and performance of the business. Based on the results of the survey, recommendations on the business environment for women engaged in MSMEs in the Philippines are provided:

1. Aggressive and in-depth information dissemination campaign on policies, programs, and services to be able to reach a broader population of women and to ensure understanding of these elements.

2. Teaching men and women alike to champion pro-women policies in any organization. Organizational policies need to reflect gender equality as well, which would reflect from recruitment to compensation. The management needs to ensure that policies, processes, procedures, and decisions are structured with due diligence and devoid of overt and covert biases.

3. Streamlining and mainstreaming government policies, programs, and services for women following the Beijing Declaration and Platform for Action in 1995, 2030 Agenda for Sustainable Development, and CEDAW.

\section{ABOUT THE AUTHOR}

The author, Myrtle Faye Laberinto Solina, was born on March 13, 1988 in Pangil, Laguna, Philippines. She took up Bachelor of Science in Agriculture major in Agricultural Extension from the University of the Philippines Los Baños (UPLB) and graduated with a Master's degree in ASEAN Studies at the University of the Philippines Open University (UPOU). She is currently affiliated with the Export Marketing Bureau (EMB) of the Department of Trade and Industry (DTI) in the Philippines. 


\section{REFERENCES}

Adrianzen, C. (2006). Marxism, Mariategui, and the Women's Movement. Peru: Movimiento Femenino Popular. www.marxists.org/subject/women/authors/adrianzen/1974.htm

ASEAN Secretariat. (2015a). ASEAN Economic Community Blueprint 2025. Indonesia: ASEAN Secretariat. www.asean.org/storage/2016/03/AECBP_2025r_FINAL.pdf

ASEAN Secretariat. (2015b). Joint Statement of the Second ASEAN Ministerial Meeting on Women $(A M M W)$. Indonesia: ASEAN Secretariat. www.asean.org/wpcontent/uploads/images/2015/November/AMMW/2nd\%20AMMW\%20Joint\%20State $\underline{\text { men.pdf }}$

ASEAN Secretariat. (2019). ASEAN Member States. Indonesia: ASEAN Secretariat. www.asean.org/asean/asean-member-states/

ASEAN Secretariat. (2019). Overview. Indonesia: ASEAN Secretariat. www.asean.org/asean/about-asean/overview/

ASEAN SME Working Group ASEAN Coordinating Committee on Micro, Small, and Medium Enterprises. (2020). SME Developments in ASEAN. Indonesia: ASEAN Secretariat. https://asean.org/asean-economic-community/sectoral-bodies-under-thepurview-of-aem/micro-small-and-medium-enterprises/overview/

Asia Pacific Foundation of Canada. (2018). 2018 Survey of Entrepreneurs and MSMEs in the Philippines: Building the Capacity of MSMEs through Market Access. Canada: APEC-Canada Growing Business Partnership. https://apfcanadamsme.ca/sites/default/files/202007/2018\%20Survey\%20of\%20Entrepreneurs $\% 20$ and $\% 20$ MSMEs $\% 20$ in $\% 20$ the $\% 20 \mathrm{P}$ hilippines_0.pdf

Çağatay, N. (2005). Gender inequalities and international trade: a theoretical reconsideration. Uruguay: Centro Interdisciplinario de Estudios sobre el Desarrollo (CIEDUR). www.ciedur.org.uy/adm/archivos/publicacion_101.pdf

Department of Consumer Affairs (DOCA) of Myanmar. (2015). Small and Medium Enterprise Development Policy. Myanmar: The Republic of the Union of Myanmar. www.doca.gov.mm/sites/default/files/Small\%20and\%20Medium\%20Enterprise \%20D evelopment $\% 20$ Policy $\% 202015$.pdf

Department of Statistics. (2019). M600981 - Topline Estimates for All Enterprises and SMEs, Annual. Singapore: Department of Statistics, Government of Singapore. www.tablebuilder.singstat.gov.sg/publicfacing/createDataTable.action?refId $=15808$

Department of Statistics. (2019). M601511 - Topline Estimates by Ownership for All Enterprises, Annual. Singapore: Department of Statistics, Government of Singapore. www.tablebuilder.singstat.gov.sg/publicfacing/createDataTable.action?refId=15807 
Department of Trade and Industry. (2017). PH Champions MSMEs, Youth and Women Entrepreneurship for ASEAN 2017 Business and Investment Program. Philippines: Department of Trade and Industry, Republic of the Philippines. www.dti.gov.ph/media/latest-news/10147-ph-champions-msmes-youth-and-womenentrepreneurship-for-asean-2017-business-and-investment-program

Department of Trade and Industry. (2020). The Organization. Philippines: Department of Trade and Industry, Republic of the Philippines. www.dti.gov.ph/about/theorganization.

Department of Trade and Industry. (2020). The Regional Operations Group. Philippines: Department of Trade and Industry, Republic of the Philippines. www.dti.gov.ph/about/the-organization/regional-operations.

Enterprise Singapore. (2019). About Enterprise Singapore. Singapore: Singapore Government. www.enterprisesg.gov.sg/about-us/overview

Gonzalez, A. and Grown, C. (2015, May 29). Women and trade: Improving conditions for success in development. World Bank Blogs. Dutch Good Growth Fund. https://blogs.worldbank.org/trade/women-and-trade-improving-conditions-successdevelopment

Holzman, C. and Roberts-Robbins, K. (2019). Serving The Financial Needs of Womenowned Business in Emerging Markets. Serving+the+financial +needs + of + womenowned+businesses +-+ Perspectives + from + the + DGGF + Portfolio.pdf

International Finance Corporation (IFC). (2019). MSME Economic Indicators Database 2019. USA: IFC SME Finance Forum. www.smefinanceforum.org/data-sites/msmecountry-indicators.

International Labor Organization (ILO). (2014). National Assessment of Women's Entrepreneurship Development in Myanmar. Switzerland: ILO. https://www.spf.org/global-data/user53/WED_ILOSPF_2019_v13_FINALonline.pdf

Kapatid Mentor Me (KMME). (2019, August 02). Negosyo. www.gonegosyo.net/programs/show/6-kapatid-mentor-me-kmme

MasterCard. (2019). Mastercard Index of Women Entrepreneurs (MIWE 2018). USA: MasterCard. www.newsroom.mastercard.com/wpcontent/uploads/2018/03/MIWE_2018_Final_Report.pdf

Micro, Small, and Medium Enterprises Development (MSMED) Council. (2017). Micro, Small, and Medium Enterprise Development (MSMED) Plan 2017-2022. Philippines: Department of Trade and Industry (DTI). www.drive.google.com/file/d/1PhDj641QsA2YmXdk1K86HsqOSz_Sooa/view

Ministry of Social Welfare Relief and Resettlement (MoSWRR). (2012). National Strategic Plan for the Advancement of Women (NSPAW) 2013 -2022. Myanmar: United 
Nations Population Fund (UNFPA). www.myanmar.unfpa.org/sites/default/files/pubpdf/NSPAW2013-2022 0.pdf

Myanmar Development Resource Institute's Centre for Economic and Social Development (MDRI-CESD). (2012). Framework for Economic and Social Reforms 2012-2015. Myanmar: MDRI-CESD. www.mdricesd.files.wordpress.com/2015/10/paper-fesr2012-15-jan-2013.pdf

Myanmar SME Development Agency. (2020). Background and History: Micro, Small, and Medium Enterprises Development Journey. Myanmar: Myanmar SME Development Agency. https://www.msme.gov.mm/en/page/background-and-history,

Organisation for Economic Co-operation and Development (OECD) Global Relations Secretariat (GRS) Southeast Europe Division and Eurasia Division. (2014). Concept Note: Revision of the SME Policy Index Methodology for the Small Business Act for Europe Assessment in the EU Pre-Accession. France: OECD. www.oecd.org/globalrelations/SME\%20Policy\%20Index\%20MethodologyConcept $\% 20$ Note.pdf

Organisation for Economic Co-operation and Development (OECD). (2013). Multidimensional Review of Myanmar: Volume 1. Initial Assessment. Myanmar: OECD Publishing. https://read.oecd-ilibrary.org/development/multi-dimensional-review-ofmyanmar 9789264202085-en\#page1

Organisation for Economic Co-operation and Development (OECD). (2018). SME Policy Index, ASEAN 2018: Boosting Competitiveness and Inclusive Growth. Paris: OECD. www.asean.org/storage/2018/08/Report-ASEAN-SME-Policy-Index-2018.pdf

Philippine Statistics Authority. (2018). Number of Establishments by Region, Section, and Employment Grouping (MSMEs), Philippines: 2018 LE. Philippines: Philippine Statistics Authority (PSA), Republic of the Philippines. https://drive.google.com/file/d/1q9CpajHqVgIV 9 3itvQYxYCRK1mZOy7/view

Philippine Statistics Authority. (2018). Total Employment by Section and Employment Groupings (MSMEs), Philippines: 2018 LE. Philippines: Philippine Statistics Authority (PSA), Republic of the Philippines.https://drive.google.com/file/d/1q9CpajHqVgIV_9 3itvQYxYCRK1mZO y7/view

Sen, A. (2001). The Many Faces of Gender Inequality. The New Republic, Harvard University. https://scholar.harvard.edu/sen/publications/many-faces-gender-inequality

Spark! Philippines. (2020). Who We Are. Philippines: Spark! Philippines. http://sparkphilippines.org/who-we-are/

Totten, D., Lwin, G. P. M. M. and van Roosmalen, M. (2019). Country Report: Myanmar Entrepreneurial Ecosystem Assessment. USA: International Finance Corporation 
(IFC) SME Finance Forum. www.smefinanceforum.org/sites/default/files/blogs/CTGCountryReport-Myanmar-Final.pdf

United Nations (UN) - Economic and Social Commission for Asia and the Pacific (ESCAP). (2017). Fostering Women's Entrepreneurship in ASEAN. Thailand: UN ESCAP. www.unescap.org/sites/default/files/ESCAP-FWE-ASEAN-full_0.pdf

Women must play a bigger role in trade. (2017, March 23). United Nations Conference on Trade and Development (UNCTAD). https://unctad.org/news/women-must-playbigger-role-trade

Woo, J. (2017, July 18). Singapore $8^{\text {th }}$ best city for women entrepreneurs. SGSME. www.sgsme.sg/news/singapore-8th-best-city-women-entrepreneurs 